\title{
Real-time PCR tests to specifically detect IHHNV lineages and an IHHNV EVE integrated in the genome of Penaeus monodon
}

\author{
Jeff A. Cowley ${ }^{1, *}$, Min Rao ${ }^{1}$, Greg J. Coman ${ }^{2}$ \\ ${ }^{1}$ Aquaculture Program, CSIRO Agriculture \& Food, Queensland Bioscience Precinct, 306 Carmody Road, St Lucia, \\ QLD 4067, Australia \\ ${ }^{2}$ Aquaculture Program, CSIRO Agriculture \& Food, Bribie Island Research Centre, 144 North Street, Woorim, \\ QLD 4507, Australia
}

\begin{abstract}
Infectious hypodermal and hematopoietic necrosis virus (IHHNV) can cause mass mortalities in western blue shrimp Penaeus stylirostris, runt deformity syndrome in Pacific white shrimp $P$. vannamei and scalloped abdominal shell deformities in black tiger shrimp P. monodon. In P. monodon, however, PCR-based diagnosis of IHHNV can be complicated by the presence of a chromosome-integrated, non-replicating endogenous viral element (EVE). To facilitate highthroughput screening of $P$. monodon for IHHNV infection and/or EVE sequences, here we report real-time PCR tests designed to specifically detect IHHNV Lineage I, II and III but not EVE Type A sequences and vice versa. Using $10^{8}$ dsDNA copies of plasmid (p)DNA controls containing either IHHNV or EVE-Type A sequences, both tests displayed absolute specificity. The IHHNV-q309 PCR reliably detected down to $\leq 10$ copies of pDNA, at which levels a 309F/R PCR amplicon was just detectable, and the presence of an IHHNV-EVE sequence did not significantly impact its sensitivity. The IHHNV-qEVE PCR was similarly sensitive. Testing of batches of $P$. monodon clinical samples from Vietnam/Malaysia and Australia identified good diagnostic concordance between the IHHNV-q309 and 309F/R PCR tests. As expected for a sequence integrated into host chromosomal DNA, IHHNV-qEVE PCR Ct values were highly uniform among samples from shrimp in which an EVE was present. The highly specific and sensitive IHHNV-q309 and IHHNV-qEVE real-time PCR tests described here should prove useful for selecting broodstock free of IHHNV infection and in maintaining breeding populations of $P$. monodon specific pathogen free for IHHNV, and if desired, also free of IHHNV-EVE sequences.
\end{abstract}

KEY WORDS: Giant tiger shrimp · Prawn · IHHNV · Infectious hypodermal and haematopoietic necrosis virus - Black tiger shrimp - Penaeus stylirostris pestyldensovirus - PstDNV - EVE · Endogenous viral element

\section{INTRODUCTION}

Infectious hypodermal and haematopoietic necrosis virus (IHHNV) is a small ( $20 \mathrm{~nm}$ diameter), nonenveloped icosahedral virus identified in the early 1980s to be the cause of mortalities in western blue shrimp Penaeus stylirostris being reared at high density in Hawaii, USA (Lightner et al. 1983a,b). Soon

${ }^{*}$ Corresponding author: jeff.cowley@csiro.au thereafter, it appeared as an asymptomatic infection in Pacific white shrimp $P$. vannamei being reared at the same facility (Lightner et al. 1983b, Bell \& Lightner 1984). Following the movement of IHHNVinfected $P$. vannamei from Hawaii to Mexico in 1987, IHHNV emerged as a serious disease in farmed $P$. stylirostris (Lightner et al. 1992, Lightner 1999). Around this time it also emerged in farmed P. van-

(C) The authors 2018. Open Access under Creative Commons by Attribution Licence. Use, distribution and reproduction are unrestricted. Authors and original publication must be credited. 
namei in the Americas as the cause of runt deformity syndrome, characterized by retarded growth and rostrum and abdominal shell deformities (Kalagayan et al. 1991, Browdy et al. 1993, Castille et al. 1993, Bray et al. 1994, Lightner et al. 2012).

While mostly detected as an asymptomatic infection in wild and farmed black tiger shrimp P. monodon (Nunan et al. 2001, Tang et al. 2003, Chayaburakul et al. 2005, Flegel 2006), acute IHHNV infection has been implicated in shell deformities including shortened rostrums and protrusions at abdominal segment joins in a cohort of $\sim 18$ mo old domesticated P. monodon bred in the Philippines (Primavera \& Quinitio 2000). IHHNV genome sequence comparisons identified little variation among strains from the Americas but substantial variation among strains from Asia (Tang \& Lightner 2002, 2006, Tang et al. 2003, Krabsetsve et al. 2004, Silva et al. 2014). This, together with historical events, pinpointed to IHHNV having been introduced to the Western Hemisphere in the late 1970s via imports of asymptomatically infected $P$. monodon from the Philippines (Tang \& Lightner 2002, Tang et al. 2003).

Based in its particle morphology and the sequence and organisation of its $\sim 4 \mathrm{~kb}$ ssDNA genome, IHHNV has been classified as the type species Decapod penstyldensovirus 1 in the genus Penstyldensovirus, subfamily Densovirinae of the Parvoviridae (Shike et al. 2000, Tang et al. 2003, Saksmerprome et al. 2010, Rai et al. 2011, King et al. 2012, Cotmore et al. 2014). For taxonomic conformity with terrestrial invertebrate densoviruses, IHHNV has been renamed Penaeus stylirostris penstyldensovirus (PstPDV) or Penaeus monodon penstyldensovirus (PmoPDV), depending on the host species of origin (Cotmore et al. 2014). However, due to varied nomenclature and acronyms currently in the literature to describe host and lineage variants, IHHNV is used here to avoid contributing to this unnecessary naming confusion.

Phylogenetic analyses of complete genome sequences of IHHNV strains from different species and/or geographic locations have identified substantial genetic variation and the clustering of strains within 3 discrete lineages (I, II and III) (Tang \& Lightner 2002, 2006, Tang et al. 2003, 2007, Saksmerprome et al. 2010, Fajardo et al. 2015). In addition to these infectious IHHNV lineages, near-complete IHHNV genome sequences with uninterrupted open reading frames (ORFs) have become integrated into the chromosomal DNA of P. monodon as an endogenous viral element (EVE) (Tang et al. 2003, 2007, Krabsetsve et al. 2004, Tang \& Lightner 2006, Rai et al. 2009, Jaroenram et al. 2015). Such IHHNV-EVE sequences are inherited through germ plasm, and $P$. monodon carrying Type A or Type B variants, or both, were first detected in shrimp from Australia, Madagascar, Tanzania, Mozambique and India (Tang et al. 2003, Krabsetsve et al. 2004, Tang \& Lightner 2006, Rai et al. 2009).

To explain why shrimp aquaculture impacts caused by a new disease generally diminish within a few years of its emergence, an active viral accommodation hypothesis has been proposed (Flegel \& Pasharawipas 1998, Flegel 2007, 2009). Primary to this hypothesis is the integration of viral genomes or genome fragments as EVEs that transcribe RNA forms (dsRNA, for example) able to interfere with viral replication. EVEs comprising near-complete (Tang et al. 2003, Tang \& Lightner 2006, Jaroenram et al. 2015) or remnant fragments of the IHHNV (Saksmerprome et al. 2011) and white spot syndrome virus genomes (de la Vega 2006, Utari et al. 2017) have been used to support this hypothesis. In the case of IHHNV, it has been speculated that single diagnostic PCR tests, unless targeted to an IHHNV genome region integrated infrequently (Jaroenram \& Owens $2014 \mathrm{a}, \mathrm{b})$, have the potential to vastly (>75\%) overestimate IHHNV infection prevalence because they amplify such IHHNV-EVEs (Saksmerprome et al. 2011). However, current key data in support of this hypothesis are either tenuous or erroneous.

Several PCR and real-time PCR tests are recommended for IHHNV diagnosis by the World Organisation for Animal Health (OIE 2017). However, as many early tests including the 77012F/77353, IHH NV389F/R and IHHNV392F/R tests (Nunan et al. 2000, Tang et al. 2000, 2007) were designed when strain/lineage sequence variations or the potential for IHHNV-EVE sequences to be cross-amplified were not recognized, care is needed in test selection and data interpretation (Tang et al. 2007, Rai et al. 2009). Tests that have considered these potential problems include the IHHNV309F/R PCR (Tang et al. 2007) and this test used as a nested PCR in conjunction with an IHHNV648F/R PCR test (Rai et al. 2009). An IHHNV-EVE specific conventional PCR test has also been designed by using a forward primer (MG831F) targeted to a 3 '-terminal region in the integrated EVE genome in conjunction with a reverse primer (MG831R) targeted to a downstream sequence within the shrimp genome (Tang et al. 2003, Tang \& Lightner 2006).

Various PCR tests multiplexed to detect IHHNV as well as other shrimp viruses (Yang et al. 2006, Khawsak et al. 2008, Xie et al. 2008) and real-time PCR tests employing either a fluorescent probe (Tang 
\& Lightner 2001) or SYBR Green dye (Dhar et al. 2001) amplicon detection methods have also been described. However, these test designs did not consider IHHNV-EVE sequences, and the extent to which they might cross-detect such EVE sequences remains to be assessed. To improve on the current repertoire of dated diagnostic PCR tests, here were describe 2 real-time PCR tests designed to either detect strains of all 3 IHHNV lineages while also excluding the commonly reported EVE sequence or vice versa. The tests should prove useful in diagnosing exogenous IHHNV strains unequivocally and enable efficient high-throughput screening to select and maintain $P$. monodon families as IHHNV-free as well as IHHNV-EVE-free should this be desired.

\section{MATERIALS AND METHODS}

\section{Shrimp}

Penaeus monodon examined included a cohort of 29 broodstock sampled within $2 \mathrm{~d}$ of being captured from the wild in either Malaysia or in Rach Goc and Da Nang provinces in Vietnam in 2015, and 24 domesticated G6 juveniles (20-25 g in weight) sampled directly from each of 3 ponds (total $=72$ ) at a farm in north Queensland, Australia, in 2016. These cohorts were selected for analysis based on IHHNV being detected using the IHHNV309F/R PCR test (Tang et al. 2007) and on F1451:PR3b PCR amplicon sequence data confirming the existence of IHHNV Lineage II and III strains in the shrimp from Malaysia/Vietnam and Australia, respectively. Pools of pleopod tissue $(n=8)$ from groups of 5 sub-adult $P$. monodon $(\mathrm{n}=40)$ being reared in a tank at a breeding facility in southeast Queensland were also tested due to the likelihood of some possessing an IHHNV-EVE. Gill tissue from the Malaysian/Vietnamese shrimp and pleopod tissue from the Australian shrimp were preserved in $70 \%$ ethanol and RNAlater $^{\mathrm{TM}}$ (Thermo Fisher Scientific), respectively. None of the shrimp examined displayed any gross signs of disease.

\section{TNA and DNA extraction}

Pieces (20-30 mg) of preserved tissue were blotted briefly on paper towel to remove excess liquid. To extract total nucleic acid (TNA = RNA + DNA), tissue was placed in $0.6 \mathrm{ml}$ RLT buffer (Qiagen) in wells of a 96-well pate, each containing 2 glass and 1 ceramic bead, and disrupted by beating for 2 min at maximum speed using a Retsch MM300 TissueLyser (MEP Instruments). Plates were centrifuged briefly and supernatants transferred to another 96-well plate, and TNA was extracted using MagJET ${ }^{\mathrm{TM}}$ RNA Kit reagents (Thermo Fisher Scientific) and a KingFisher ${ }^{\mathrm{TM}}$ Flex Purification System (Thermo Fisher Scientific) using the manufacturer's recommended protocol, except for omitting the DNase I digestion step and including an additional Wash Buffer 2 step. DNA was extracted using MagJET ${ }^{\text {TM }}$ DNA Kit reagents (Thermo Fisher Scientific) and a KingFisher ${ }^{\mathrm{TM}}$ Flex Purification System using the manufacturer's recommended protocol except for use of an additional Wash Buffer 2 step. The concentration and relative purity of TNA/DNA eluted in $50 \mu \mathrm{l}$ RNase/ DNase-free water were estimated using a Nanodrop ND8000 spectrophotometer, and TNA/DNA aliquots were normalized to $100 \mathrm{ng}^{-1} \mathrm{l}^{-1}$ using RNase-free water. Plates of stock and normalized TNA/DNA were stored at $-80^{\circ} \mathrm{C}$ until analysed.

\section{Sequence alignments to select PCR primers and probes}

To identify genome target sites for real-time PCR tests to discriminate sequences of IHHNV Lineages I, II and III strains from IHHNV-EVE sequences, fulland near full-length sequences and selected partial sequences available in GenBank were aligned using ClustalX_2.1 (Larkin et al. 2007) and reformatted using BioEdit_V7.2.5 (Hall 1999). The IHHNV sequences were from multiple penaeid species (P. monodon, P. vannamei, P. stylirostris, P. enicillatus) examined over a 2 decade period (1991-2014) from countries including Australia, Brazil, China, Ecuador, India, South Korea, Taiwan, Thailand and Vietnam. The IHHNV-EVE Type A and B sequences were detected in P. monodon examined between 1993 and 2012 from Australia, Madagascar and East Africa. The multiple sequence alignment was initially scanned visually for regions of high nucleotide identity among IHHNV lineages coinciding with IHHNV-EVE nucleotide variation (Figs. S1 \& S2 in the Supplement at www.int-res.com/articles/suppl/ d129p145_supp.pdf).

Of several potential test target sites, sequence around the IHHNV-specific 309F PCR primer (Tang et al. 2007) in the NS1 ORF just downstream of the NS2 ORF was used to select IHHNV-q309 TaqMan real-time PCR test primer/probe sequences conserved among strains of IHHNV Lineages I, II and III 
(Figs. 1 \& S1). Based on nearby upstream and downstream sequences being highly conserved among IHHNV strains, a probe targeted to the 309F primer sequence and flanking primers meeting acceptable real-time PCR sequence and annealing temperature design criteria were selected with the aid of Primer 3 V0.4.0 (Koressaar \& Remm 2007, Untergasser et al. 2012), Primer Express 3.0 (Applied Biosystems) and OligoCalc V3.27 (Kibbe 2007) software (Table 1). To maximize specificity of the 5'-[6FAM]-probe for IHHNV sequences, a 3'-minor groove binder nonfluorescent quencher (MGB-NFQ) group was selected to markedly reduce probe length without reducing its annealing temperature (de Kok et al. 2002).

A 3 '-untranslated region (3'-UTR) sequence downstream of the VP1 ORF at which IHHNV-EVE Type A sequences varied markedly from IHHNV Lineage I, II or III sequences was selected for design of the EVEspecific IHHNV-qEVE PCR test (Figs. 1 \& S2). PCR primer and 5'-[6FAM]-probe sequences were designed as above (Table 1). However, as it was possible to design PCR primers that also included substantial nucleotide mismatches, the non-fluorescent 3'-Black Hole Quencher ${ }^{\circledR}-1$ (BHQ-1) chromophore (Biosearch Technologies) was selected as the probe 3 '-quencher moiety to reduce synthesis costs and improve the consistency and signal-to-noise ratio compared to 6-carboxy- $\mathrm{N}, \mathrm{N}, \mathrm{N}^{\prime}, \mathrm{N}^{\prime}$-tetramethylrhodamine (TAMRA ${ }^{\mathrm{TM}}$, Glen Research) fluorescence quencher (Yang et al. 2009, Leal et al. 2013). As the single available IHHNV EVE Type B sequence does not extend into this 3'-genome region (Tang et al. 2003, Tang \& Lightner 2006, Fig. S2), it remains to be assessed whether the IHHNV-qEVE PCR test will detect this EVE variant.

As a real-time PCR test control for template DNA amount and integrity, elongation factor $1-\alpha / \beta$ (EF1$\alpha / \beta)$ gene sequences available in GenBank for penaeid shrimp species including $P$. monodon, $P$. vannamei and $P$. japonicus were aligned using ClustalX_2.1 and BioEdit_V7.2.5 as above and scanned visually for regions displaying high levels of sequence conservation (Fig. S3). EF1 PCR primer and probe sequences were selected that (1) targeted conserved sequence regions, (2) met acceptable realtime PCR design criteria, (3) resided downstream of the known intron to facilitate detection of both DNA and RNA/cDNA and (4) considered the potential for amino acid codon wobble to afford the test good prospects for detecting EF1 gene sequences from diverse penaeid species (Fig. S3, Table 1). As in the IHHNV-qEVE PCR test, the shrimp EF1qF1/R1 PCR test probe incorporated a 5'-[6FAM] fluorophore and 3'-BHQ-1 quencher.

\section{Plasmid DNA controls}

Fragments of an IHHNV genome and a genomeintegrated IHHNV-EVE sequence were amplified by PCR using TNA extracted from several P. monodon from Vietnam/Malaysia or Australia that had been identified by PCR to be either infected with IHHNV but not carry an EVE sequence or to possess an EVE in the absence or near absence of IHHNV. The F1451:R3b PCR primer pair was used to amplify a $638 \mathrm{bp}$ Region 1 (R1) portion of the IHHNV and IHHNV-EVE sequences, and the F3031:R3782 PCR primer pair was used to amplify $752 \mathrm{bp}$ and $755 \mathrm{bp}$ Region 2 (R2) portions of the IHHNV genome and IHHNV-EVE sequences, respectively (Fig. 1). Sequences of the PCR primers are detailed in Table 1. Amplified DNA was purified using a QIAquick PCR column (Qiagen), cloned into pGEM-T-Easy vector (Promega), and colony PCR employing the universal M13F:M13R primer pair was used to select clones
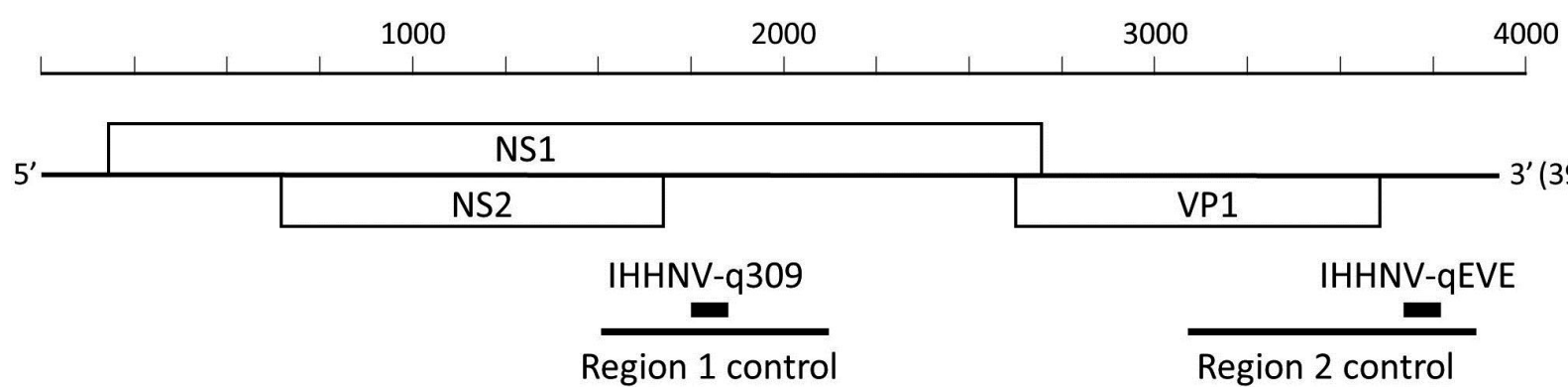

VP1

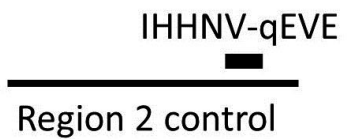

Fig. 1. Schematic representation of an IHHNV genome, showing the relative positions of the NS1, NS2 and VP1 open reading frames as well as Region 1 (F1451:R3b PCR primer pair) and Region 2 (F3031:R3782 PCR primer pair) sequences amplified by PCR from IHHNV Lineages II/III and IHHNV-EVE Type A sequences and cloned for use as specificity controls for the IHHNVq309 and IHHNV-qEVE PCR tests. Positions are shown for the genome sequence of an IHHNV Lineage II strain (VN2007) detected in Penaeus vannamei in Vietnam in 2007 (GenBank accession no. KF031144). 


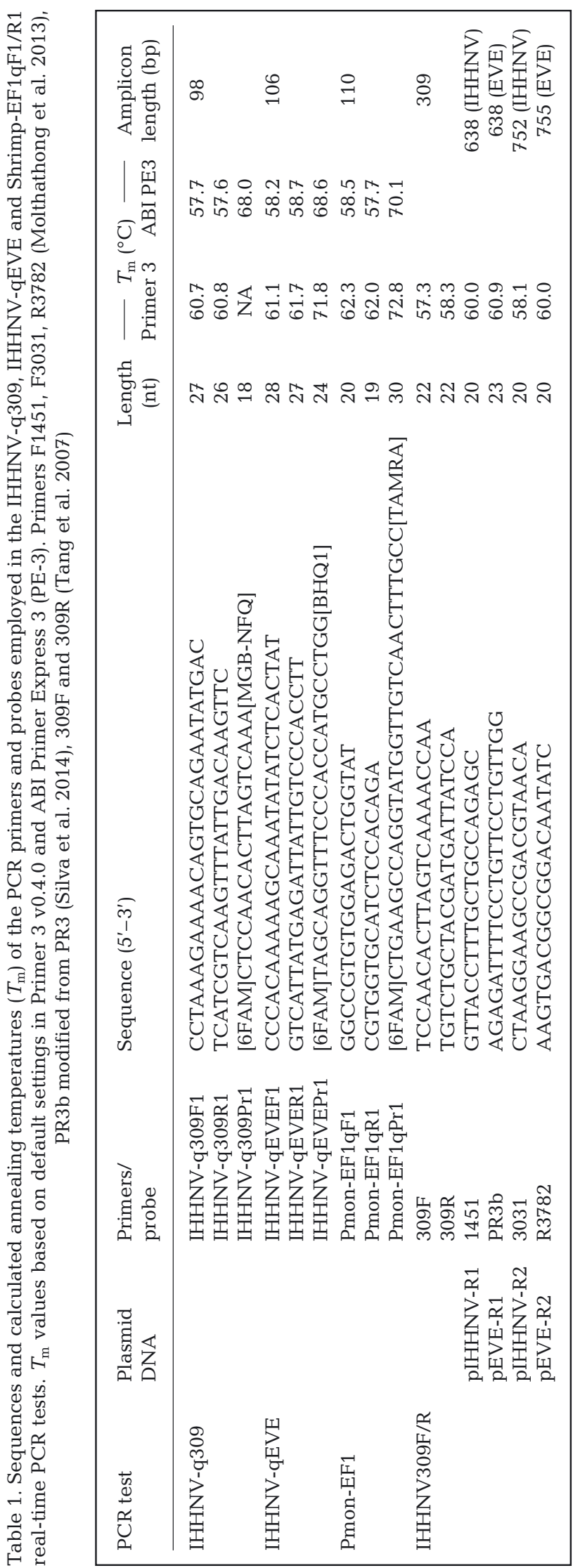

containing inserts of the expected length. Following the overnight growth of mini cultures, high-purity pDNA was extracted using a Plasmid DNA MiniPREP Kit (Qiagen), and pDNA eluted in EB buffer (Qiagen) was diluted to $10 \mathrm{ng} \mathrm{pl}^{-1}$ in RNase-free water and stored at $-20^{\circ} \mathrm{C}$. DNA inserts in multiple independent pDNA clones containing each of the IHHNV-R1, EVE-R1, IHHNV-R2 and EVE-R2 PCR products were sequenced in both directions using BigDye Terminator V3.1 reagent (Applied Biosystems), T7 or SP6 primer and a 3130xl Genetic Analyzer (Applied Biosystems). Following sequence chromatogram analysis using Sequencher 5.4.5 (Gene Codes), GenBank BLASTn (NCBI) searches were undertaken to confirm that an IHHNV Lineage II and IHHNV-EVE Type A sequence had been amplified and cloned. Clone insert sequences were aligned to highlight PCR primer binding positions (Figs. S4 \& S5).

To prepare stocks of selected pIHHNV-R1, pEVER1, pIHHNV-R2 and pEVE-R2 plasmid (p)DNA of known dsDNA copy number, an aliquot of each pDNA (10 $\mathrm{ng}^{-1} \mathrm{l}^{-1}$ ) was analysed using a Nanodrop 8000 UV spectrophotometer. Based on the $A_{260 n m}$ value and molecular mass data deduced for each plasmid dsDNA sequence using OligoCalc V3.27, DNA copies $\mu^{-1}$ were calculated. An aliquot of each pDNA was diluted accordingly in $10 \mathrm{ng}^{\mathrm{l}} \mathrm{l}^{-1}$ salmon sperm DNA in RNase-free water to prepare stocks containing $2 \times 10^{8} \mathrm{dsDNA}$ copies $\mathrm{\mu l}^{-1}$, which were stored in aliquots at $-20^{\circ} \mathrm{C}$ and used to prepare serial 10 -fold dilutions in RNase/DNase free water to assess PCR test specificity and sensitivity.

\section{PCR tests}

Oligonucleotides purified using Bio-RP resin cartridges and BHQ1-quencher probes purified by HPLC were purchased from Bioneer Pacific. The MBG-NFQ probe purified by HPLC was purchased from Integrated DNA Technologies. Sequences and properties of the PCR primers and probes employed in the IHHNV-q309, IHHNV-qEVE and shrimpEF1qF1/R1 real-time PCR tests are detailed in Table 1. For each test, reactions $(20 \mu \mathrm{l})$ were prepared to contain $1 \times$ SensiFAST $^{\text {TM }}$ Probe Lo-ROX mastermix (Bioline), $0.9 \mu \mathrm{M}$ each primer, $0.25 \mu \mathrm{M}$ probe and normalized amounts (100 or $200 \mathrm{ng}$ depending on batch concentration range) of shrimp TNA or DNA. Reaction aliquots (5 $\mu$ l containing 25 or 50 ng DNA/TNA) were dispensed into each of 3 wells of a 384-well real-time PCR plate as technical replicates using an EpMotion 5075 liquid handling robot 
(Eppendorf). DNA was amplified using a ViiA 7 RealTime PCR System (Applied Biosystems) and a thermal cycling profile $\left(95^{\circ} \mathrm{C}\right.$ for 2 min for polymerase activation, 40 cycles of $95^{\circ} \mathrm{C}$ for $15 \mathrm{~s}, 60^{\circ} \mathrm{C}$ for $30 \mathrm{~s}$ ) within the parameters recommended in the SensiFAST $^{\mathrm{TM}}$ Probe Lo-ROX Kit instructions (Bioline).

For the IHHNV-specific PCR test employing the IHHNV309F/R primer pair (Tang et al. 2007), reactions (25 $\mu$ l) contained 1× Taq Reaction Buffer (Invitrogen), $1.5 \mathrm{mM} \mathrm{MgCl}_{2}, 200 \mathrm{nM}$ dNTP mixture, 5 pmole each primer, 50 ng TNA or DNA and 1.25 U Taq DNA polymerase (Invitrogen). Thermal cycling conditions were $94^{\circ} \mathrm{C}$ for $2 \mathrm{~min}, 35$ cycles of $94^{\circ} \mathrm{C}$ for $30 \mathrm{~s}, 55^{\circ} \mathrm{C}$ for $30 \mathrm{~s}$, $72^{\circ} \mathrm{C}$ for $40 \mathrm{~s}$ followed by $72^{\circ} \mathrm{C}$ for $7 \mathrm{~min}$ and $20^{\circ} \mathrm{C}$ hold using a Veriti ${ }^{\mathrm{TM}}$ cycler (Applied Biosystems). An aliquot (5-8 $\mu$ l depending on gel well volume) of each PCR was electrophoresed in a $2 \%$ agarose-TAE gel containing $0.5 \mu \mathrm{g} \mathrm{ml} \mathrm{m}^{-1}$ ethidium bromide, and the 309 bp DNA band was visualized and documented using a GelDoc 2000 UV transilluminator (BioRad).

To compare the analytical specificities and sensitivities of the IHHNV309F/R, IHHNV-q309 and IHHNVqEVE PCR tests, and to generate standard curves for IHHNV-q309 and IHHNV-qEVE PCR test quantification purposes, serial 10-fold dilutions of pIHHNV-R1, pEVE-R1, pIHHNV-R2 and pEVE-R2 plasmid DNAs of calculated dsDNA copy number were prepared in $10 \mathrm{ng} \mathrm{\mu l}^{-1}$ salmon sperm DNA in RNase-free water and stored at $-20^{\circ} \mathrm{C}$ until used. An aliquot (1-2 $\left.\mu \mathrm{l}\right)$ of each dilution containing between $1 \times 10^{8}$ and 0.1 pDNA copies reaction ${ }^{-1}$ (5 $\mu$ l for real-time PCR, $25 \mu \mathrm{l}$ for PCR), as well as a water no-template control (NTC), were amplified as described. To identify any impact of the presence of the IHHNV-EVE on IHHNV-q309 PCR detection sensitivity, serial 10-fold dilutions of pIHHNV-R1 DNA were prepared as above except for spiking the diluent with pEVE-R1 DNA at a concentration predetermined empirically to generate a cycle threshold (Ct) value (21-23) comparable to that uniformly detected in clinical samples from shrimp carrying an EVE sequence.

\section{RESULTS}

\section{IHHNV-q309, IHHNV-qEVE and shrimp-EF1qF1/R1 real-time PCR test designs}

To provide specificity, the 3'MGB-NFQ probe employed in the IHHNV-specific IHHNV-q309 PCR test was designed to mismatch at $6 \mathrm{nt}$ positions (including a continuous stretch of $4 \mathrm{nt}$ ) with the EVE Type A sequences available in GenBank, and at $4 \mathrm{nt}$ positions $(2,4,9,11)$ dispersed across the 18-mer probe with the single reported EVE Type B sequence (AY124937, Tang et al. 2003, 2007, Tang \& Lightner 2006). Compared to EVE Type A sequences, the IHHNV-q309 PCR primers also mismatched at 3 to $4 \mathrm{nt}$ positions (Fig. S1). The EVE-specific IHHNVqEVE PCR test was targeted to an untranslated region downstream of the ORF3 gene in which IHHNV-EVE Type A sequences varied markedly from IHHNV Lineage I, II and III strain sequences (Fig. S2). Unlike the IHHNV-q309 PCR, the nature of this region was more conducive to designing PCR primers, rather than a probe, to more highly divergent sequences while having these meet real-time PCR primer/probe design criteria. In particular, the 28 nt EVEqF1 PCR primer mismatched at 16 nt positions $(57 \%)$ including a consecutive stretch of $6 \mathrm{nt}$ and a mismatch at its 3' terminus. The EVEqR1 PCR primer also varied at 7/27 positions and the 3'BHQ1 probe varied at $4 / 24$ positions. The shrimp-EF1qF1/ R1 PCR test primers and 3'BHQ1 probe targeted sequences conserved among all elongation factor 1 (EF1) gene sequences available in GenBank for 3 penaeid shrimp species (Fig. S3). The test also targeted an exon so that it could be used to validate relative amounts and/or purity of DNA and RNA in extracts of clinical samples from these and potentially other shrimp species.

\section{Linearity and sensitivity of the IHHNV and IHHNV-EVE real-time PCR tests}

The linearity and analytical sensitivity of the IHHNV-q309 and IHHNV-qEVE real-time PCR tests were assessed initially using serial 10-fold dilutions of either the pIHHNV-R1/pEVE-R1 or pEVE-R2/ pIHHNV-R2 plasmid DNA controls, respectively, of calculated dsDNA copy number (Table 2). Regression plots identified the IHHNV-q309 and IHHNVqEVE PCR tests to amplify pDNA at comparable efficiencies $\left(\mathrm{R}^{2}=0.998\right)$ irrespective of their use of probes containing either $3^{\prime} \mathrm{MGB}-\mathrm{NFQ}$ or $3{ }^{\prime} \mathrm{BHQ}-1$ fluorescence quenchers, respectively. Both tests also displayed a linear dynamic range extended from at least $10^{8}$ to below 100 dsDNA copies, with data for the IHHNV q309 PCR test suggesting it to be slightly more efficient compared to the IHHNV-qEVE test (i.e. dsDNA detection in $3 / 3$ and $1 / 3$ replicate wells compared to $2 / 3$ and $0 / 3$ wells at 10 and 1 dsDNA copies well ${ }^{-1}$, respectively) (Table 2). Signal-to-noise ratios calculated by dividing fluorescence signal levels at Cycle 40 by background signal levels at Cycle 
1 for each dsDNA copy number tested were slightly higher for the IHHNV-q309 $(5.3 \pm 0.3)$ compared to the IHHNV-qEVE PCR test $(4.0 \pm 0.2)$, and remained relatively unchanged as dsDNA template amounts reduced. The IHHNV-q309 PCR test generated no Ct value with the EVE-R1 pDNA control, and the IHHNV-qEVE PCR test generated no $\mathrm{Ct}$ value with the pIHHNV-R2 pDNA control when tested using $10^{8}$ dsDNA copies reaction ${ }^{-1}$, thus confirming test specificity (Table 2).

The analytical specificity and sensitivity of the conventional 1-step IHHNV309F/R PCR test (Tang et al. 2007) was also evaluated using the same serial 10-fold dilutions of pIHHNV-R1 and pEVE-R1 DNA used to evaluate the IHHNV-q309 PCR (Fig. 2). With this test, a $\sim 0.3 \mathrm{~kb}$ DNA band was clearly detected (+ to +++ ) by agarose gel electrophoresis at $\geq 100$ pIHHNV-R1 dsDNA copies reaction ${ }^{-1}$ and just detected (-/+) at 10 dsDNA copies reaction ${ }^{-1}$ (Fig. 2). No DNA band of the expected size was detected with any pEVE-R1 DNA dilutions tested at up to $10^{8}$ dsDNA copies reaction ${ }^{-1}$.

\section{Potential for an EVE sequence to quench IHHNV- q309 PCR detection of low levels of IHHNV}

The IHHNV-q309 PCR test specificity was dictated primarily by the sequence specificity of the short TaqMan-MGB probe. Thus as potential existed for the PCR primers to co-amplify integrated IHHNVEVE sequences, when present, we examined whether the presence of an IHHNV-EVE sequence might quench detection of low loads of IHHNV. To assess this, the IHHNV-q309 PCR test was run using 10 -fold dilutions of pIHHNV-1 pDNA prepared in either buffer alone or buffer spiked with pEVE-1 pDNA adjusted to a concentration predetermined to approximate the IHHNV-qEVE PCR Ct value expected in clinical samples from shrimp carrying a genome-integrated IHHNV-EVE sequence (Table 3). IHHNV-q309 PCR Ct values varied little at higher pIHHNV-1 pDNA copy numbers, and at copy numbers approaching the test sensitivity limits, $\mathrm{Ct}$ values

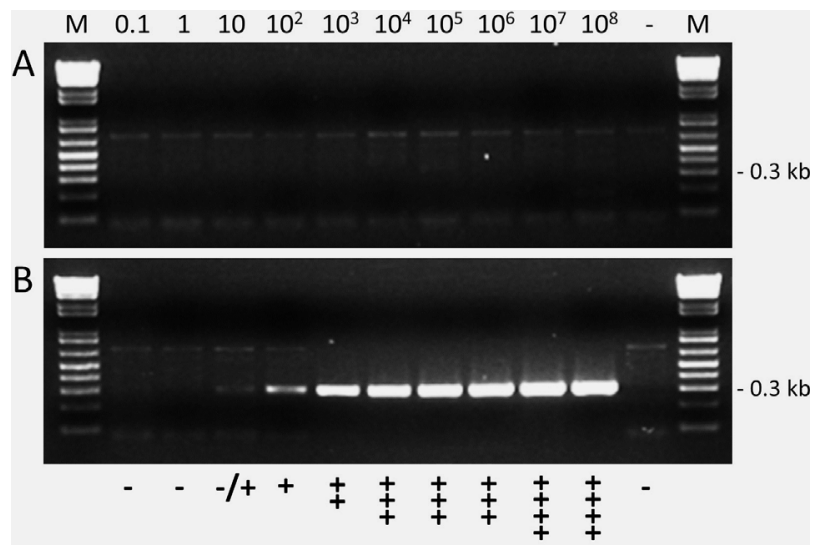

Fig. 2. Agarose gel electrophoresis of DNA amplified using the IHHNV309F/R 1-step PCR and serial 10-fold dilutions of Region 1 (A) IHHNV-EVE pDNA and (B) IHHNV pDNA ranging from 0.1 to $10^{8}$ dsDNA copies reaction ${ }^{-1}$. An $8 \mu \mathrm{l}$ aliquot of each $25 \mu \mathrm{l}$ reaction was analysed. No-template control reaction (-), $\mathrm{M}=1 \mathrm{~kb}$ PLUS DNA ladder (Life Technologies). Relative visual amounts of $\sim 0.3 \mathrm{~kb}$ DNA amplified for each IHHNV pDNA dilution are indicated (- to ++++)

Table 2. Cycle-threshold (Ct) values obtained with the IHHNV-q309 and IHHNV-qEVE PCR tests using 10-fold dilution series of pIHHNV-R1 and pEVE-R2 plasmid DNA, respectively, as well as $10^{8} \mathrm{dsDNA}$ copies of each reciprocal plasmid DNA. NTC: no-template controls (water); UD: undetermined; Rep: technical replicate wells $\times 3$. For IHHNV-q309 PCR: slope $=-3.304, y$ intercept $=37.4, \mathrm{R}^{2}=0.998$, efficiency $=100.7 \%$, error $=0.037$; for IHHNV-qEVE PCR test: slope $=-3.312, y$-intercept $=39.6$, $\mathrm{R}^{2}=0.998$, efficiency $=100.4 \%$, error $=0.035$

\begin{tabular}{|c|c|c|c|c|c|c|c|c|c|}
\hline \multirow{2}{*}{$\begin{array}{l}\text { pIHHNV-R1 } \\
\text { dsDNA copies }\end{array}$} & \multicolumn{4}{|c|}{- IHHNV-q309 PCR } & \multirow{2}{*}{$\begin{array}{l}\text { pEVE-R2 } \\
\text { dsDNA copies }\end{array}$} & \multirow[b]{2}{*}{ Rep 1} & \multicolumn{3}{|c|}{ IHHNV-qEVE PCR } \\
\hline & Rep 1 & Rep 2 & Rep 3 & Mean \pm SD & & & Rep 2 & Rep 3 & Mean $\pm \mathrm{SD}$ \\
\hline 0.1 & UD & UD & UD & - & & & & & \\
\hline 1.0 & UD & UD & 33.15 & - & & & & & \\
\hline 10 & 33.64 & 32.66 & 32.30 & $32.87 \pm 1.47$ & 10 & 32.60 & 37.35 & UD & $36.31 \pm 0.69$ \\
\hline $10^{2}$ & 29.57 & 29.79 & 29.46 & $29.61 \pm 0.17$ & $10^{2}$ & 32.60 & 32.93 & 32.83 & $32.79 \pm 0.17$ \\
\hline $10^{3}$ & 26.12 & 26.44 & 26.31 & $26.29 \pm 0.24$ & $10^{3}$ & 29.98 & 29.50 & 29.66 & $29.71 \pm 0.16$ \\
\hline $10^{4}$ & 23.36 & 23.34 & 23.5 & $23.35 \pm 0.09$ & $10^{4}$ & 26.57 & 26.72 & 26.58 & $26.62 \pm 0.09$ \\
\hline $10^{5}$ & 19.95 & 19.64 & 19.85 & $19.82 \pm 0.12$ & $10^{5}$ & 22.89 & 22.70 & 22.91 & $22.83 \pm 0.16$ \\
\hline $10^{6}$ & 16.83 & 16.88 & 16.85 & $16.85 \pm 0.05$ & $10^{6}$ & 19.71 & 19.73 & 19.63 & $19.69 \pm 0.03$ \\
\hline $10^{7}$ & 14.24 & 14.21 & 14.15 & $14.20 \pm 0.05$ & $10^{7}$ & 16.34 & 16.42 & 16.35 & $16.37 \pm 0.05$ \\
\hline $10^{8}$ & 11.11 & 11.04 & 11.16 & $11.10 \pm 0.06$ & $10^{8}$ & 13.17 & 13.07 & 13.09 & $13.11 \pm 0.06$ \\
\hline $10^{8} \mathrm{pEVE-R} 1$ & UD & UD & UD & - & $10^{8}$ pIHHNV-R2 & UD & UD & UD & - \\
\hline NTC & UD & UD & UD & - & NTC & UD & UD & UD & - \\
\hline
\end{tabular}


were either slightly lower or only detected with the pIHHNV-1 pDNA diluted in buffer spiked with pEVE-1 pDNA. However, as IHHNV-q309 test Ct values were only recorded for 2 of the 3 technical replicates at the 10 and 1 pIHHNV-1 pDNA copy number dilutions containing pEVE-1 pDNA, minor quenching cannot be discounted without testing of a large number of such dilutions. IHHNV-qEVE PCR Ct values varied little (range 23.0-23.4) across the pIHHNV-1 pDNA dilutions (0.01-10 $0^{8}$ DNA copies) prepared in buffer spiked with pEVE-1 pDNA, indicating that EVE detection will not be quenched by high-level IHHNV infection.

\section{IHHNV and IHHNV-EVE real-time PCR tests assessed using clinical samples}

The performance of the IHHNV-q309 and IHHNVqEVE real-time PCR tests was compared to that of the OIE-recommended conventional IHHNV309F/R PCR test (Tang et al. 2007) using samples from wild and farmed Penaeus monodon sourced from locations in Vietnam and Malaysia in 2015 and from Queensland, Australia, in 2016 (Tables 4 \& 5). Of the DNA extracts from the 29 wild broodstock from Vietnam/Malaysia, tested using the IHHNV309F/R PCR, 17 generated a $0.3 \mathrm{~kb}$ DNA band clearly detectable following agarose gel electrophoresis and another 7 generated a DNA band (-/+ score) that was just visi-

Table 3. IHHNV-q309 and IHHNV-qEVE PCR mean cycle threshold (Ct) values obtained using a 10-fold dilution series of IHHNV pDNA prepared either in buffer alone or buffer containing of IHHNV-EVE pDNA at a concentration mimicking that expected in shrimp clinical samples carrying a genome-integrated IHHNV-EVE. UD: undetermined (no $\mathrm{Ct}$ value); NTC: no-template control

\begin{tabular}{|c|c|c|c|c|}
\hline \multirow{2}{*}{$\begin{array}{l}\text { pIHHNV-1 } \\
\text { pDNA dsDNA } \\
\text { copy no. }\end{array}$} & \multicolumn{2}{|c|}{ pIHHNV-R1 pDNA } & \multicolumn{2}{|c|}{$\begin{array}{l}\text { pIHHNV-1 pDNA } \\
\text { in pEVE-R1 pDNA }\end{array}$} \\
\hline & q309 PCR & qEVE PCR & q309 PCR & qEVE PCR \\
\hline 0.01 & UD & UD & UD & $23.03 \pm 0.08$ \\
\hline 0.1 & UD & UD & UD & $23.08 \pm 0.11$ \\
\hline 1.0 & UD & UD & $37.73 \pm 0.78^{a}$ & $23.20 \pm 0.05$ \\
\hline 10 & $37.47 \pm 4.13$ & UD & $35.18 \pm 0.63^{a}$ & $23.22 \pm 0.11$ \\
\hline $10^{2}$ & $32.76 \pm 0.50$ & UD & $32.71 \pm 0.22$ & $23.37 \pm 0.02$ \\
\hline $10^{3}$ & $29.03 \pm 0.25$ & UD & $29.66 \pm 0.31$ & $23.20 \pm 0.08$ \\
\hline $10^{4}$ & $25.63 \pm 0.04$ & UD & $26.05 \pm 0.08$ & $23.27 \pm 0.05$ \\
\hline $10^{5}$ & $22.29 \pm 0.04$ & UD & $22.62 \pm 0.12$ & $23.24 \pm 0.07$ \\
\hline $10^{6}$ & $18.96 \pm 0.14$ & UD & $19.29 \pm 0.12$ & $23.20 \pm 0.04$ \\
\hline $10^{7}$ & $15.56 \pm 0.10$ & UD & $15.92 \pm 0.09$ & $23.03 \pm 0.16$ \\
\hline $10^{8}$ & $12.81 \pm 0.65$ & UD & $12.72 \pm 0.09$ & $23.27 \pm 0.04$ \\
\hline NTC & UD & UD & UD & UD \\
\hline
\end{tabular}

ble (Table 4 ; Fig. S6 $;+$ to ++++ score based on relative IHHNV309F/R DNA product amounts as shown in Fig. 2). In comparison, of the 28 DNA extracts tested using the IHHNV-q309 PCR, 16 generated a mean $\mathrm{Ct}$ value $<34$ ( $3 / 3$ technical replicate wells). Of the 9 samples that generated a $\mathrm{Ct}$ value $>34,3$ each generated $\mathrm{Ct}$ values in $3 / 3,2 / 3$ or $1 / 3$ technical replicate wells. Of the $5 \mathrm{IHHNV} 309 \mathrm{~F} / \mathrm{R}$ test negatives, 3 were negative in all 3 technical replicate wells of the IHHNV-q309 test, and 2 generated a Ct value $>36$ in 1 or 2 of the 3 replicate wells. In general, IHHNVq309 PCR test Ct values correlated well with DNA band intensities scored subjectively for the IHHNV309F/R PCR test, and IHHNV infection prevalence and loads were higher among the P. monodon broodstock from Malaysia (Table 4). When tested using the IHHNV-qEVE PCR test, 3 of the 29 DNA samples (Shrimp 16, 17, 29) generated a uniform Ct value (range 22.0-22.3). Using the Shrimp-EF1qF1/R1 PCR test to assess DNA quality and quantity, a relatively uniform Ct value (range 19.0-21.1) was obtained across all 29 samples.

Of the TNA extracts from the 72 P. monodon from a farm in north Queensland, the IHHNV309F/R PCR test, all 72 DNA generated a $0.3 \mathrm{~kb}$ DNA band clearly detectable following agarose gel electrophoresis (++ to +++ score) (Table 5). When tested using the IHHNVq309 PCR, all 72 samples also tested positive at Ct values ranging from 10.3 to 21.8. In general, IHHNV-q309 PCR Ct values correlated well with DNA product amounts amplified by the IHHNV309F/R PCR. None of the 72 DNA samples generated a $\mathrm{Ct}$ value when tested using the IHHNV-qEVE PCR, but all generated a relatively uniform Ct value (range 21.0-22.9) using the Shrimp-EF1qF1/R1 PCR test.

To ensure that the IHHNV-qEVE PCR detected IHHNV-EVE sequences known to exist in Australian P. monodon, another sample batch comprising 8 pools of pleopod tissue each from 5 P. monodon ( $\mathrm{n}=40$ shrimp) sampled from a tank at a breeding facility in southeast Queensland was tested (Table 6). The IHHNV-q309 test detected IHHNV at variable loads in all 8 pools (Ct range 12.0-24.6), and the IHHNV-qEVE PCR test detected EVE sequences in only $5 / 8$ pools at variable loads (Ct range 21.4-25.3), indicative of only some shrimp in these pools possessing an EVE. 


\section{IHHNV and IHHNV-EVE sequences}

To verify which IHHNV lineages and EVE types had been amplified by PCR from Malaysian P. monodon and cloned to produce pDNA to evaluate the analytical performance of the IHHNV-q309 and IHHNV-qEVE PCR tests, consensus sequences of the IHHNV and IHHNV-EVE pDNA inserts that spanned each of the test target sites were used in BLAST searches of GenBank (Figs. S4 \& S5). In addition to the pDNA clone sequences amplified from

Table 4. Real-time IHHNV-q309, IHHNV-qEVE and Shrimp EF1 PCR test data compared to IHHNV309F/R PCR test data generated using DNA extracted from gill tissue of 29 wild Penaeus monodon broodstock captured at locations in Vietnam (A: Rach Goc; B: Da Nang) and Malaysia (C) in 2015. Ct: cycle threshold; UD: undetermined; NTC: no-template control; NS: no sample available to test

\begin{tabular}{|c|c|c|c|c|c|}
\hline \multirow{2}{*}{$\begin{array}{l}\text { Shrimp } \\
\text { No. }\end{array}$} & \multirow{2}{*}{ Origin } & \multirow{2}{*}{$\begin{array}{c}\mathrm{PCR}^{\mathrm{a}} \\
309 \mathrm{~F} / \mathrm{R}\end{array}$} & \multicolumn{3}{|c|}{ PCR test mean $\mathrm{Ct}$ values } \\
\hline & & & IHHNV & EVE & EF1 \\
\hline 1 & A & $-/+$ & 36.06 & UD & 20.41 \\
\hline 2 & A & +++ & 18.77 & UD & 19.84 \\
\hline 3 & $\mathrm{~A}$ & - & UD & UD & 20.84 \\
\hline 4 & A & +++ & 19.11 & UD & 20.51 \\
\hline 5 & A & + & $37.37^{\mathrm{b}}$ & UD & 20.27 \\
\hline 6 & A & ++ & 22.98 & UD & 20.69 \\
\hline 7 & $\mathrm{~A}$ & - & UD & UD & 20.82 \\
\hline 8 & A & $-/+$ & $37.89^{\mathrm{c}}$ & UD & 20.44 \\
\hline 9 & A & - & $39.06^{\mathrm{c}}$ & UD & 19.04 \\
\hline 10 & A & + & 30.83 & UD & 21.06 \\
\hline 15 & B & - & UD & UD & 20.75 \\
\hline 16 & B & + & 29.49 & 22.26 & 20.63 \\
\hline $17^{b}$ & B & $-/+$ & $36.92^{\mathrm{c}}$ & 22.20 & 20.36 \\
\hline 18 & B & $-/+$ & 33.99 & UD & 20.88 \\
\hline 19 & B & $-/+$ & $34.29^{b}$ & UD & 19.84 \\
\hline 20 & B & $-1+$ & $36.92^{\mathrm{b}}$ & UD & 19.56 \\
\hline 23 & B & + & 22.01 & UD & 20.55 \\
\hline 24 & B & - & 37.97 & UD & 19.51 \\
\hline 25 & B & +++ & NS & UD & 19.82 \\
\hline 28 & $\mathrm{C}$ & + & 30.45 & UD & 18.61 \\
\hline 29 & $\mathrm{C}$ & + & 29.09 & 22.02 & 20.35 \\
\hline 30 & $\mathrm{C}$ & ++ & 24.78 & UD & 19.54 \\
\hline 31 & $\mathrm{C}$ & ++ & 24.62 & UD & 19.18 \\
\hline 32 & $\mathrm{C}$ & ++ & 27.74 & UD & 19.35 \\
\hline 33 & $\mathrm{C}$ & $-/+$ & 36.15 & UD & 19.13 \\
\hline 36 & $\mathrm{C}$ & +++ & 20.04 & UD & 19.46 \\
\hline 37 & $\mathrm{C}$ & ++ & 26.18 & UD & 19.42 \\
\hline 38 & $\mathrm{C}$ & + & 29.75 & UD & 19.55 \\
\hline $39^{\mathrm{a}}$ & $\mathrm{C}$ & ++++ & 12.44 & UD & 19.92 \\
\hline NTC & & - & UD & UD & UD \\
\hline \multicolumn{6}{|c|}{$\begin{array}{l}\text { a Relative DNA amounts detected by gel electrophoresis } \\
(-/+ \text { to }++++) \\
\text { bSamples giving an IHHNV } 309 \text { PCR Ct value in } 2 / 3 \\
\text { replicates }\end{array}$} \\
\hline \multicolumn{6}{|c|}{$\begin{array}{l}\text { 'Samples giving an IHHNV } 309 \mathrm{PCR} \text { Ct value in } 1 / 3 \\
\text { replicates }\end{array}$} \\
\hline
\end{tabular}

wild P. monodon broodstock from Malaysia, GenBank was also searched using IHHNV PCR product sequences amplified similarly from representatives of the cohort of farmed $P$. monodon examined from Australia. For the 595 nt IHHNV genome region internal to the F1451:PR3b PCR primer pair to which the IHHNV-q309 PCR test was targeted, the Malaysian IHHNV strain was identical in sequence to an IHHNV Lineage II strain (Taiwan isolate $B$, AY355307) detected in farmed $P$. monodon from Taiwan in the early 2000s (Hsia et al. 2003), and the 595 nt EVE sequence detected in some of these $P$. monodon possessed only a single nucleotide difference to an EVE Type A sequence (DQ228358) first detected in P. monodon from Madagascar in 2001 (Tang et al. 2003, Tang \& Lightner 2006). BLAST searches identified that the IHHNV genome region amplified from of the Australian $P$. monodon was identical to IHHNV Lineage III strains detected in $P$. vannamei in China (KU373072, KP733861, Wei et al. 2015) and P. monodon from Taiwan (AY335306, AY335308, Hsia et al. 2003).

For the 712 nt IHHNV genome region internal to the F3031:R3782 PCR primer pair to which the IHHNV-qEVE PCR test was targeted, the Malaysian IHHNV strain sequence was identical to an IHHNV Lineage II strain (Taiwan isolate B, AY355307), and the 715 nt sequence of an EVE detected in some of these $P$. monodon possessed only a single nucleotide difference to EVE Type A sequences (KM593913, EU675312, DQ228358).

\section{DISCUSSION}

The IHHNV-specific and IHHNV-EVE-specific real-time PCR tests described here display absolute specificity for synthetic DNA sequences generated to the most commonly reported Lineage II and III strains of IHHNV and the Type A IHHNV-EVE. To maximize specificity of the IHHNV-q309 PCR test, a short (18-mer) TaqMan 3'MGB-NFQ probe was targeted to the same ORF1 gene region targeted by the 309F PCR primer used to provide specificity in a conventional IHHNV309F/R PCR test (Tang et al. 2007) that remains recommended for IHHNV diagnosis in the OIE Manual of Diagnostic Tests for Aquatic Animals (OIE 2017). This ORF1 gene region was also attractive as it allowed consensus PCR primer and probe sequences meeting real-time PCR criteria to be targeted to genome regions highly conserved among IHHNV Lineage I, II and III strain sequences available in GenBank. A 3'MGB-NFQ was selected 
Table 5. Real-time IHHNV-q309, IHHNV-qEVE and Shrimp EF1 PCR test data compared to IHHNV309F/R PCR test data generated using total nucleic acid (TNA = DNA + RNA) extracted from pleopod tissue of 72 Penaeus monodon sampled from 3 ponds at a farm in north Queensland, Australia, in 2016. Ct: cycle threshold; UD: undetermined; NTC: no-template control

\begin{tabular}{|c|c|c|c|c|c|c|c|c|c|}
\hline \multirow{2}{*}{$\begin{array}{l}\text { Shrimp } \\
\text { no. }\end{array}$} & \multirow{2}{*}{$\begin{array}{c}\mathrm{PCR}^{\mathrm{a}} \\
309 \mathrm{~F} / \mathrm{R}\end{array}$} & \multicolumn{3}{|c|}{ PCR test mean $\mathrm{Ct}$ values } & \multirow{2}{*}{$\begin{array}{l}\text { Shrimp } \\
\text { no. }\end{array}$} & \multirow{2}{*}{$\begin{array}{c}\mathrm{PCR}^{\mathrm{a}} \\
309 \mathrm{~F} / \mathrm{R}\end{array}$} & \multicolumn{3}{|c|}{ PCR test mean $\mathrm{Ct}$ values } \\
\hline & & IHHNV & EVE & EF1 & & & IHHNV & EVE & EF1 \\
\hline 1 & ++ & 21.15 & UD & 22.48 & 37 & ++ & 11.57 & UD & 21.80 \\
\hline 2 & ++ & 21.72 & UD & 21.92 & 38 & ++ & 10.30 & UD & 22.47 \\
\hline 3 & ++ & 14.68 & UD & 22.24 & 39 & ++ & 11.26 & UD & 22.35 \\
\hline 4 & ++ & 21.56 & UD & 21.32 & 40 & ++ & 10.70 & UD & 21.97 \\
\hline 5 & ++ & 20.69 & UD & 22.09 & 41 & +++ & 10.98 & UD & 22.22 \\
\hline 6 & ++ & 21.77 & UD & 22.02 & 42 & +++ & 11.83 & UD & 21.86 \\
\hline 7 & ++ & 11.57 & UD & 21.79 & 43 & +++ & 11.75 & UD & 22.90 \\
\hline 8 & ++ & 11.85 & UD & 22.16 & 44 & +++ & 10.50 & UD & 21.31 \\
\hline 9 & ++ & 19.95 & UD & 21.80 & 45 & +++ & 11.32 & UD & 21.19 \\
\hline 10 & ++ & 18.95 & UD & 22.15 & 46 & +++ & 11.08 & UD & 22.07 \\
\hline 11 & ++ & 15.48 & UD & 21.06 & 47 & +++ & 10.54 & UD & 21.36 \\
\hline 12 & ++ & 21.08 & UD & 22.18 & 48 & +++ & 11.93 & UD & 21.98 \\
\hline 13 & ++ & 20.36 & UD & 21.68 & 49 & +++ & 11.36 & UD & 22.03 \\
\hline 14 & ++ & 12.60 & UD & 21.93 & 50 & +++ & 13.56 & UD & 22.98 \\
\hline 15 & ++ & 19.14 & UD & 21.55 & 51 & +++ & 11.75 & UD & 22.11 \\
\hline 16 & ++ & 14.00 & UD & 22.00 & 52 & +++ & 11.58 & UD & 21.81 \\
\hline 17 & ++ & 12.50 & UD & 21.45 & 53 & ++ & 11.83 & UD & 22.87 \\
\hline 18 & ++ & 21.91 & UD & 21.75 & 54 & ++ & 12.76 & UD & 21.05 \\
\hline 19 & ++ & 14.40 & UD & 21.20 & 55 & ++ & 13.41 & UD & 21.79 \\
\hline 20 & ++ & 12.58 & UD & 22.24 & 56 & ++ & 12.23 & UD & 21.48 \\
\hline 21 & ++ & 20.06 & UD & 21.50 & 57 & ++ & 13.04 & UD & 22.06 \\
\hline 22 & ++ & 17.98 & UD & 21.43 & 58 & ++ & 13.10 & UD & 21.61 \\
\hline 23 & ++ & 21.45 & UD & 22.20 & 59 & ++ & 12.77 & UD & 21.67 \\
\hline 24 & ++ & 20.48 & UD & 21.85 & 60 & ++ & 14.23 & UD & 21.15 \\
\hline 25 & ++ & 14.54 & UD & 21.84 & 61 & ++ & 11.77 & UD & 21.65 \\
\hline 26 & ++ & 13.23 & UD & 22.04 & 62 & ++ & 11.36 & UD & 21.85 \\
\hline 27 & ++ & 12.65 & UD & 21.01 & 63 & ++ & 12.33 & UD & 21.45 \\
\hline 28 & ++ & 13.81 & UD & 21.44 & 64 & ++ & 12.12 & UD & 21.13 \\
\hline 29 & ++ & 11.45 & UD & 21.56 & 65 & +++ & 12.52 & UD & 21.96 \\
\hline 30 & ++ & 17.07 & UD & 22.66 & 66 & +++ & 11.44 & UD & 21.59 \\
\hline 31 & ++ & 12.66 & UD & 21.42 & 67 & +++ & 11.48 & UD & 21.92 \\
\hline 32 & ++ & 14.38 & UD & 22.39 & 68 & +++ & 11.25 & UD & 21.21 \\
\hline 33 & ++ & 14.00 & UD & 21.66 & 69 & +++ & 11.86 & UD & 22.30 \\
\hline 34 & ++ & 11.80 & UD & 21.64 & 70 & +++ & 12.53 & UD & 21.85 \\
\hline 35 & ++ & 13.22 & UD & 21.79 & 71 & +++ & 11.19 & UD & 21.71 \\
\hline 36 & ++ & 12.92 & UD & 21.14 & 72 & +++ & 11.31 & UD & 21.74 \\
\hline $\mathrm{IHHNV}^{\mathrm{b}}$ & +++ & 14.90 & UD & UD & & & & & \\
\hline $\mathrm{EVE}^{\mathrm{c}}$ & - & UD & 11.21 & UD & & & & & \\
\hline NTC & - & UD & UD & UD & & & & & \\
\hline
\end{tabular}

to quench probe fluorescence due to it stabilizing base-pairing (Afonina et al. 1997, Kutyavin et al. 1997), thus reducing its length and tolerance to template mismatches compared to probes using either 3'TAMRA or 3'BHQ for fluorescence quenching (Kutyavin et al. 2000, Yao et al. 2006). Combined, the primer and probe design features prevented the IHHNV-q309 PCR test from amplifying even high amounts $\left(10^{8}\right.$ dsDNA copies) of EVE Type A pDNA. Its sensitivity also equalled or bettered that of the IHHNV309F/R PCR test (Tang et al. 2007).
The IHHNV-q309 PCR primers were not designed specifically to prevent IHHNV-EVE Type A or B sequences from being amplified. Despite this, IHHNVq309 PCR test Ct values and detection sensitivity limit were not compromised significantly when IHH NV pDNA was serially diluted in a uniform concentration of EVE Type A pDNA mimicking that detected in EVE-positive shrimp using the IHHNVEVE specific IHHNV-qEVE PCR. In relation its potential to cross-detect the EVE Type B sequence, studies examining how multiple template mismatches 
Table 6. Mean \pm SD IHHNV-q309 and IHHNV-qEVE PCR cycle threshold $(\mathrm{Ct})$ values obtained with total nucleic acid (TNA = DNA + RNA) extracted from 8 pools of pleopod tissue each from 5 domesticated Penaeus monodon broodstock sampled from a breeding facility in southeast Queensland, Australia, in February 2017. UD: undetermined (no Ct value)

\begin{tabular}{|lcc|}
\hline $\begin{array}{l}\text { Pool no. } \\
\text { (5 tissue pieces) }\end{array}$ & IHHNV-q309 & IHHNV-qEVE \\
\hline 1 & $13.85 \pm 0.09$ & \\
2 & $13.30 \pm 0.09$ & UD \\
3 & $20.62 \pm 0.04$ & UD \\
4 & $13.64 \pm 0.09$ & UD \\
5 & $14.20 \pm 0.03$ & $21.44 \pm 0.02$ \\
6 & $12.02 \pm 0.13$ & $23.57 \pm 0.05$ \\
7 & $14.35 \pm 0.09$ & $24.31 \pm 0.21$ \\
8 & $24.63 \pm 0.07$ & $24.63 \pm 0.11$ \\
IHHNV +ve & $10.97 \pm 0.04$ & UD \\
IHHNV-EVE +ve & UD & $14.99 \pm 0.08$ \\
NTC & UD & UD \\
& & \\
\hline
\end{tabular}

destabilize base-pairing of 3'MGB-NFQ probes (Kutyavin et al. 2000, Whiley \& Sloots 2006, Yao et al. 2006) suggest that the $4 \mathrm{nt}$ template mismatches spread across the 18-mer IHHNV-q309 PCR probe would markedly reduce amplicon detection. However, in the absence of clinical samples from Penaeus monodon from Tanzania in which the EVE Type B sequence has been identified to exist (Tang et al. 2003, Tang \& Lightner 2006), this will need to be confirmed by testing of a synthetic EVE Type B DNA sequence.

Unlike the IHHNV-q309 PCR test in which specificity was provided primarily by nucleotide mismatches in the probe sequence, specificity of the EVE-specific IHHNV-qEVE PCR test was provided by targeting a genome region conducive to the design of PCR primers containing substantial nucleotide mismatches between EVE Type A sequences and those of reported strains of IHHNV Lineages I, II and III. In particular, the 28 nt EVEqF1 PCR primer mismatched at $16 \mathrm{nt}$ positions including a consecutive stretch of $6 \mathrm{nt}$ and a 3 ' terminal nt mismatch, well in excess of that identified to cause amplification failure of other PCR tests (Boyle et al. 2009, Stadhouders et al. 2010, Ledeker \& De Long 2013, Lefever et al. 2013). As the high proportion of mismatches in the IHHNV-qEVE PCR test primers alone was expected to provide excellent specificity, a 3'BHQ1 rather than a 3 'MGB-NFQ probe was employed to reduce synthesis costs and improved test signal-to-noise relative to 3'TAMRA (Yang et al. 2009, Leal et al. 2013). While its detection sensitivity approached that of the IHHNV-q309 PCR ( 10 dsDNA copies), as IHHNV-
EVE sequences are integrated in shrimp chromosomal DNA (Tang et al. 2003, 2007, Krabsetsve et al. 2004, Tang \& Lightner 2006), when present, high sensitivity is not be critical for the IHHNV-qEVE PCR due to EVE DNA template being uniformly abundant. Accordingly, when normalized shrimp DNA amounts were tested, IHHNV-qEVE PCR Ct values were highly uniform (23-24) irrespective of whether IHHNV was also present. EVE Type A sequences were detected in P. monodon from Vietnam/Malaysia and Australia, and when tissue pooled from 5 shrimp was tested and recorded a $\mathrm{Ct}$ value, these varied more among samples presumably due to variations in the number of shrimp in each pool carrying an EVE. As the EVE Type B sequence has not been determined across IHHNV-qEVE PCR test target site, whether it will also be detected effectively is not known. However, as this EVE type has only been described once in a batch of $P$. monodon from Tanzania (Tang et al. 2003, Tang \& Lightner 2006), whether it occurs in $P$. monodon indigenous to other regions remains to be determined.

The real-time PCR protocols described here used a 384-well PCR plate format and $3 \times 5 \mu$ reaction volumes aliquoted from a $20 \mu \mathrm{l}$ reaction as technical replicates. Combined with accurate robotic liquid dispensing, such technical replicates can improve data confidence for each sample and provide an opportunity to discount data outliers resulting from a technical problem with a single well. However, the use of a single $20 \mu \mathrm{l}$ reaction in a 96-well PCR plate format would be expected to improve detection sensitivity, potentially by a factor of 4 (2 Ct values). However, the trade-off of relying on a single reaction is reduced data confidence, particularly for samples in which the IHHNV DNA template amount is extremely low and approaching the test detection sensitivity limit.

In addition to the IHHNV- and EVE-specific PCR tests, a real-time PCR test was designed to detect the shrimp elongation factor 1 (EF1) gene as a control for DNA extract integrity, yield and purity. The ShrimpEF1qF1/R1 test primers and probe were targeted to sequences conserved among EF1 $\alpha$ and EF1 $\beta$ gene sequences available in GenBank for P. monodon, $P$. vannamei and $P$. japonicus. When DNA concentrations of extract batches were normalized, the test generated highly uniform Ct values (21-22 range). These data suggest that the test will be useful in validating the amount and integrity of input DNA extracted from shrimp tissues and thus in identifying potential false negatives or DNA detection deficiencies caused by sample inadequacies. Through PCR 
primer limiting combined with the use of a probe conjugated to 5'JOE rather than 5'6FAM, for example, potential exists to multiplex the ShrimpEF1qF1/R1 PCR test, or the IHHNV-qEVE test, with the IHHNV-q309 PCR test. While such test multiplexing is attractive as a means of reducing test numbers, costs and data turn-around times, it has yet to be investigated.

In summary, the highly specific IHHNV-q309 and IHHNV-qEVE PCR tests described here should provide a reliable high-throughput means of efficiently and accurately (1) detecting and differentiating the commonly reported IHHNV-EVE Type A sequence from infectious IHHNV genome lineages in clinical samples, (2) determining the IHHNV infection status and/or quantifying IHHNV infection loads in wildcaptured broodstock before their use in hatcheries and (3) establishing and certifying breeding populations of P. monodon as specific pathogen free for IHHNV, and if also desired, as free from IHHNVEVE Type A sequences.

Acknowledgements. We thank Gold Coast Marine Aquaculture and Viet Uc shrimp companies for financial support and supplying Penaeus monodon for testing.

\section{LITERATURE CITED}

Afonina I, Zivarts M, Kutyavin I, Lukhtanov E, Gamper H, Meyer RB (1997) Efficient priming of PCR with short oligonucleotides conjugated to a minor groove binder. Nucleic Acids Res 25:2657-2660

* Bell TA, Lightner DV (1984) IHHN virus: infectivity and pathogenicity studies in Penaeus stylirostris and Penaeus vannamei. Aquaculture 38:185-194

Boyle B, Dallaire N, MacKay J (2009) Evaluation of the impact of single nucleotide polymorphisms and primer mismatches on quantitative PCR. BMC Biotechnol 9:75

Bray WA, Lawrence AL, Leung-Trujillo JR (1994) The effect of salinity on growth and survival of Penaeus vannamei with observations on the interaction of IHHN virus and salinity. Aquaculture 122:133-146

Browdy CL, Holloway JD, King CO, Stokes AD, Hopkins JS, Sandifer PA (1993) IHHN virus and intensive culture of Penaeus vannamei: effects of stocking density and water exchange rates. J Crustac Biol 13:87-94

Castille FL, Samocha TM, Lawrence AL, He H, Frelier P, Jaenike F (1993) Variability in growth and survival of early postlarval shrimp (Penaeus vannamei Boone 1931). Aquaculture 113:65-81

Chayaburakul K, Lightner DV, Sriurairattana S, Nelson KT, Withyachumnarnkul B (2005) Different responses to infectious hypodermal and hematopoietic necrosis virus (IHHNV) in Penaeus monodon and P. vannamei. Dis Aquat Org 67:191-200

Cotmore SF, Agbandje-McKenna M, Chiorini JA, Mukha DV and others (2014) The family Parvoviridae. Arch Virol 159:1239-1247 de Kok JB, Wiegerinck ETG, Giesendorf BAJ, Swinkels DW (2002) Rapid genotyping of single nucleotide polymorphisms using novel minor groove binding DNA oligonucleotides (MGB probes). Hum Mutat 19:554-559

de la Vega E (2006) A molecular approach to study the interaction between environmental stress immune response and disease in the black tiger prawn (Penaeus monodon). $\mathrm{PhD}$ thesis, The University of Queensland, Brisbane

Dhar AK, Roux MM, Klimpel KR (2001) Detection and quantification of infectious hypodermal and hematopoietic necrosis virus and white spot virus in shrimp using realtime quantitative PCR and SYBR green chemistry. J Clin Microbiol 39:2835-2845

Fajardo C, Rodulfo H, Rodriguez M, Puig J, De Donato M (2015) Molecular characterization of strains of decapod penstyldensovirus 1 (PstDV1) isolated in farmed Litopenaeus vannamei from Venezuela. Aquaculture 436: 34-39

Flegel TW (2006) Detection of major penaeid shrimp viruses in Asia: a historical perspective with emphasis on Thailand. Aquaculture 258:1-33

Flegel TW (2007) Update on viral accommodation, a model for host-viral interaction in shrimp and other arthropods. Dev Comp Immunol 31:217-231

* Flegel TW (2009) Hypothesis for heritable, anti-viral immunity in crustaceans and insects. Biol Direct 4:32

Flegel TW, Pasharawipas T (1998) Active viral accommodation: a new concept for crustacean response to viral pathogens. In: Flegel TW (ed) Advances in shrimp biotechnology. National Center for Genetic Engineering and Biotechnology, Bangkok, p 245-250

Hall TA (1999) BioEdit: a user-friendly biological sequence alignment editor and analysis program for Windows 95/98/NT. Nucl Acids Symp Ser 41:95-98

Hsia HL, Chen LL, Peng SE, Yu HT, Lo CF, Kou GH (2003) Comparison of genomic sequence of infectious hypodermal and hematopoietic necrosis virus (IHHNV) between Taiwan and other geographical isolates. Fish Pathol 38: 177-179

Jaroenram W, Owens L (2014a) Separation of endogenous viral elements from infectious Penaeus stylirostris densovirus using recombinase polymerase amplification. Mol Cell Probes 28:284-287

Jaroenram W, Owens L (2014b) Recombinase polymerase amplification combined with a lateral flow dipstick for discriminating between infectious Penaeus stylirostris densovirus and virus-related sequences in shrimp genome. J Virol Methods 208:144-151

Jaroenram W, Chaivisuthangkura P, Owens L (2015) One base pair deletion and high rate of evolution: keys to viral accommodation of Australian Penaeus stylirostris densovirus. Aquaculture 443:40-48

Kalagayan H, Godin D, Kanna R, Hagino G, Sweeney J, Wyban J, Brock J (1991) IHHN virus as an etiological factor in runt deformity syndrome (RDS) of juvenile Penaeus vannamei cultured in Hawaii. J World Aquacult Soc 22:235-243

Khawsak P, Deesukon W, Chaivisuthangkura P, Sukhumsirichart W (2008) Multiplex RT-PCR assay for simultaneous detection of six viruses of penaeid shrimp. Mol Cell Probes 22:177-183

Kibbe WA (2007) OligoCalc: an online oligonucleotide properties calculator. Nucleic Acids Res 35:W43-W46

King AMQ, Adams MJ, Carstens EB, Lefkowitz EJ (2012) Virus taxonomy: classification and nomenclature of 
viruses. Ninth Report of the International Committee on Taxonomy of Viruses. Elsevier/Academic Press, London Koressaar T, Remm M (2007) Enhancements and modifications of primer design program Primer3. Bioinformatics 23:1289-1291

Krabsetsve K, Cullen BR, Owens L (2004) Rediscovery of the Australian strain of infectious hypodermal and haematopoietic necrosis virus. Dis Aquat Org 61: 153-158

Kutyavin IV, Afonina IA, Mills A, Gorn VV and others (2000) 3'-Minor groove binder-DNA probes increase sequence specificity at PCR extension temperatures. Nucleic Acids Res 28:655-661

Larkin MA, Blackshields G, Brown NP, Chenna R and others (2007) Clustal W and Clustal X version 20. Bioinformatics 23:2947-2948

Leal CAG, Carvalho-Castro GA, Cottorello AC, Leite RC, Figueiredo HCP (2013) Comparative analysis of conventional PCR and real-time PCR to diagnose shrimp WSD. Braz J Microbiol 44:901-904

Ledeker BM, De Long SK (2013) The effect of multiple primer-template mismatches on quantitative PCR accuracy and development of a multi-primer set assay for accurate quantification of pcrA gene sequence variants. J Microbiol Methods 94:224-231

Lefever S, Pattyn F, Hellemans J, Vandesompele J (2013) Single-nucleotide polymorphisms and other mismatches reduce performance of quantitative PCR assays. Clin Chem 59:1470-1480

Lightner DV (1999) The penaeid shrimp viruses TSV, IHHNV, WSSV and YHV: current status in the Americas, available diagnostic methods, and management strategies. J Appl Aquacult 9:27-52

Lightner DV, Redman RM, Bell TA (1983a) Infectious hypodermal and hematopoietic necrosis, a newly recognized virus disease of penaeid shrimp. J Invertebr Pathol 42: 62-70

Lightner DV, Redman RM, Bell TA, Brock JA (1983b) Detection of IHHN virus in Penaeus stylirostris and $P$. vannamei imported into Hawaii. J World Maric Soc 14: 212-225

Lightner DV, Bell TA, Redman RM, Perez LA (1992) A collection of case histories documenting the introduction and spread of the virus disease IHHN in penaeid shrimp culture facilities in Northwestern Mexico. ICES Mar Sci Symp 194:97-105

* Lightner DV, Redman RM, Pantoja CR, Tang KFJ and others (2012) Historic emergence, impact and current status of shrimp pathogens in the Americas. J Invertebr Pathol 110:174-183

Molthathong S, Jitrakorn S, Joyjinda Y, Boonchird C and others (2013) Persistence of Penaeus stylirostris densovirus delays mortality caused by White spot syndrome virus infection in black tiger shrimp (Penaeus monodon). BMC Vet Res 9:33

Nunan LM, Poulos BT, Lightner DV (2000) Use of polymerase chain reaction for the detection of infectious hypodermal and hematopoietic necrosis virus in penaeid shrimp. Mar Biotech 2:319-328

* Nunan LM, Arce SM, Staha RJ, Lightner DV (2001) Prevalence of infectious hypodermal and hematopoietic necrosis virus (IHHNV) and white spot syndrome virus (WSSV) in Litopenaeus vannamei in the Pacific Ocean off the coast of Panama. J World Aquacult Soc 32: 330-334
OIE (World Organisation for Animal Health) (2017) Manual of diagnostic tests for aquatic animals. http://www.oie. int/standard-setting/aquatic-manual/access-online/

* Primavera JH, Quinitio ET (2000) Runt-deformity syndrome in cultured giant tiger prawn Penaeus monodon. J Crustac Biol 20:796-802

Kai P, Pradeep B, Safeena MP, Karunasagar I, Karunasagar I (2009) Simultaneous presence of infectious hypodermal and hematopoietic necrosis virus (IHHNV) and Type A virus-related sequence in Penaeus monodon from India. Aquaculture 295:168-174

* Rai P, Safeena MP, Karunasagar I, Karunasagar I (2011) Complete nucleic acid sequence of Penaeus stylirostris densovirus (PstDNV) from India. Virus Res 158:37-45

* Saksmerprome V, Puiprom O, Noonin C, Flegel TW (2010) Detection of infectious hypodermal and haematopoietic necrosis virus (IHHNV) in farmed Australian Penaeus monodon by PCR analysis and DNA sequencing. Aquaculture 298:190-193

* Saksmerprome V, Jitrakorn S, Chayaburakul K, Laiphrom S, Boonsua K, Flegel TW (2011) Additional random single to multiple genome fragments of Penaeus stylirostris densovirus in the giant tiger shrimp genome have implications for viral disease diagnosis. Virus Res 160:180-190

Shike H, Dhar AK, Burns JC, Shimizu C, Jousset FX, Klimpel KR, Bergoin M (2000) Infectious hypodermal and hematopoietic necrosis virus of shrimp is related to mosquito brevidensoviruses. Virology 277:167-177

Silva DCD, Nunes ARD, Teixeira DIA, Lima JPMS, Lanza DCF (2014) Infectious hypodermal and hematopoietic necrosis virus from Brazil: sequencing comparative analysis and PCR detection. Virus Res 189:136-146

Stadhouders R, Pas SD, Anber J, Voermans J, Mes THM, Schutten M (2010) The effect of primer-template mismatches on the detection and quantification of nucleic acids using the 5' nuclease assay. J Mol Diagn 12:109-117

Tang KFJ, Lightner DV (2001) Detection and quantification of infectious hypodermal and hematopoietic necrosis virus in penaeid shrimp by real-time PCR. Dis Aquat Org 44:79-85

Tang KFJ, Lightner DV (2002) Low sequence variation among isolates of infectious hypodermal and hematopoietic necrosis virus (IHHNV) originating from Hawaii and the Americas. Dis Aquat Org 49:93-97

*Tang KFJ, Lightner DV (2006) Infectious hypodermal and hematopoietic necrosis virus (IHHNV)-related sequences in the genome of the black tiger prawn Penaeus monodon from Africa and Australia. Virus Res 118: 185-191

Tang KFJ, Durand SV, White BL, Redman RM, Pantoja CR, Lightner DV (2000) Postlarvae and juveniles of a selected line of Penaeus stylirostris are resistant to infectious hypodermal and hematopoietic necrosis virus infection. Aquaculture 190:203-210

Tang KFJ, Poulos BT, Wang J, Redman RM, Shih HH, Lightner DV (2003) Geographic variations among infectious hypodermal and hematopoietic necrosis virus (IHHNV) isolates and characteristics of their infection. Dis Aquat Org 53:91-99

Tang KFJ, Navarro SA, Lightner DV (2007) PCR assay for discriminating between infectious hypodermal and hematopoietic necrosis virus (IHHNV) and virus-related sequences in the genome of Penaeus monodon. Dis Aquat Org 74:165-170 
Untergasser A, Cutcutache I, Koressaar T, Ye J, Faircloth BC, Remm M, Rozen SG (2012) Primer3 - new capabilities and interfaces. Nucleic Acids Res 40:e115

Utari HB, Soowannayan C, Flegel TW, Whityachumnarnkul B, Kruatrachue M (2017) Variable RNA expression from recently acquired endogenous viral elements (EVE) of white spot syndrome virus (WSSV) in shrimp. Dev Comp Immunol 76:370-379

Wei YW, Fan DD, Chen J (2015) Development of an overlapping PCR method to clone the full genome of infectious hypodermal and hematopoietic necrosis virus (IHHNV). J Virol Methods 224:16-19

Whiley DM, Sloots TP (2006) Sequence variation can affect the performance of minor groove binder TaqMan probes in viral diagnostic assays. J Clin Virol 35:81-83

Xie Z, Xie L, Pang Y, Lu Z and others (2008) Development of

Editorial responsibility: Hamish Small,

Gloucester Point, Virginia, USA a real-time multiplex PCR assay for detection of viral pathogens of penaeid shrimp. Arch Virol 153:2245-2251

* Yang B, Song XL, Huang J, Shi CY, Liu QH, Liu L (2006) A single-step multiplex PCR for simultaneous detection of white spot syndrome virus and infectious hypodermal and haematopoietic necrosis virus in penaeid shrimp. J Fish Dis 29:301-305

* Yang GP, Erdman DD, Tondella ML, Fields BS (2009) Evaluation of tetramethylrhodamine and black hole quencher 1 labelled probes and five commercial amplification mixes in TaqMan real-time RT-PCR assays for respiratory pathogens. J Virol Methods 162:288-290

Yao Y, Nellåker C, Karlsson H (2006) Evaluation of minor groove binding probe and TaqMan probe PCR assays: influence of mismatches and template complexity on quantification. Mol Cell Probes 20:311-316

Submitted: January 30, 2018; Accepted: May 7, 2018 Proofs received from author(s): June 18, 2018 